\title{
Kulaktan yabancı cisim çıkarılmasında pratik bir yöntem
}

\author{
A practical method for removing foreign bodies from the ear
}

\author{
Sedat Aydın (1) \\ Sağlık Bilimleri Üniversitesi, Kartal Dr. Lütfi Kırdar Ĕ̆itim ve Araştırma Hastanesi, \\ Kulak Burun Boğaz Kliniği, İstanbul, Türkiye
}

Üç yaşında kız çocuğu üçüncü basamak referans hastanemizin acil servisine, kaza sonucu diş kulak yoluna kaçan yabancı cisim nedeniyle getirildi. Annesi çocuğun oynarken kulağına küçük yuvarlak küre şeklinde bir plastik parçası soktuğunu ve ilk başvurduğu sağl1k merkezinde kulak yıkama şırıngası ile kulak lavajı yapıldığını, ardından mikroskop yardımıyla çeşitli aletler kullanılarak yuvarlak olan yabancı cismin çıkarılmaya çalışı1dığını ancak denemeler sonucunda yabancı cismin çıkarılamadığ 1 gibi daha derine kulak zarına kadar ilerlediğini ve sonuçta hastanemize sevk edildiğini belirtti.

Diş kulak yolunda yabancı cisimler çocuklarda sık görülmektedir. Sert olan yabancı cisimler genellikle diş kulak yolunun istmus bölgesinin lateralinde yerleşimli ise şırınga ile kulağa lavaj yapılarak çıkarılabilmektedir. Ancak istmus bölgesinin medial kısmına ilerlemiş ise ve hatta yabancı cisim boncuk gibi küre şeklinde yuvarlak ise, o zaman otolojik mikrocerrrahi aletleri kullanilarak genel anesteziyle çıkarılmaktadır. Hasta ilk muayenesinden sonra acil servisten Kulak Burun Boğaz (KBB) hekimine yönlendirildi. Yapılan KBB muayenesinde diş kulak yolu ödemli, şiş, kan pihtıları ve salgı ile dolu idi bu nedenle yabancı cisim görülemiyordu. Bunun üzerine hasta ebeveyn onayı alındiktan sonra Acil servisteki ameliyathaneye alındı. Genel anestezi altında ameliyat mikroskopu yardımıyla dış kulak yolundaki pıhtı ve salgılar temizlendi. Dış kulak yoluna adrenalin emdirilmiş pamuklar üç dakika süreyle uygulanarak kanama kontrolü sağlandi.
Acil servis ameliyathanesinde kulak ameliyatları sik olarak yapılmadığından otoskopik mikrocerrahi aletleri yoktu. Bu aletlerin ana binadaki 2. katta bulunan ameliyathaneden getirilmesi gerekiyordu. $\mathrm{Bu}$ da yaklaşık 30-45 dakikalık bir gecikme yaşanacağ1 ve dolayısıyla üç yaşındaki bir çocuğun anestezik gaz alacağı anlamını taşıyordu. Bu sırada kanca benzeri bir alet olması durumunda çocuğun dış kulak yolundaki yabancı cismin çıkarılmasının mümkün olabileceği düşüncesiyle oradaki personelden 5 mL'lik steril tekli pakette bulunan bir enjektör ve portequ istedim. Portequ ile enjektör iğnesinin ucunu boncuğun çevresine uygun çapta kanca şeklinde kıvırdım. Sonra ameliyat mikroskopu altında kanca şeklinde kıvrılmış iğne ucunu boncuğun oturdu$\breve{g u}$ diş kulak yolunun alt kısmındaki anterior timpanik

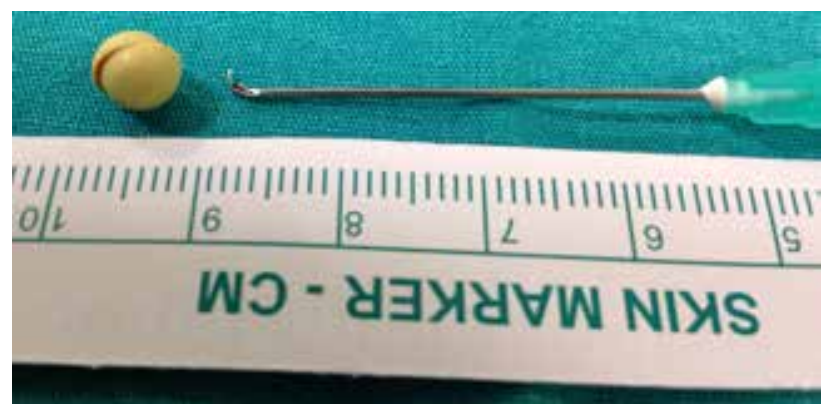

Şekil 1. Kulaktan çıkarılan yabancı cisim ve ucu kanca haline getirilmiş enjektör ucu görülmektedir. 
açıdan uygun açıklıktan sokarak yavaşça laterale doğru hareket ettirebildim ancak ilk denemede çıkmadı daha sonra farklı açılardan iki-üç denemeyle boncuk benzeri yabancı cismi dı̧̧ kulak yolundan çıkarabildim (Şekil 1).

Sonuç olarak mikrocerrahi yapmış olan bir KBB hekiminin yeterli cihazların olmadığ 1 mahrumiyet bölgelerinde çalışırken dı̧̧ kulak yolunda yabancı cisim ile başvuran bir çocuğu "elimde mikrocerrahi aletleri yok" diye doğrudan bir üniversite hastanesine göndermeden önce bir enjektör ucu ile bu tip durumlara çözüm bula- bileceklerini kendi deneyimimi paylaşarak belirtmek istedim.

\section{Çıkar çakışması beyanı}

Yazar bu yazının hazırlanması ve yayınlanması aşamasında herhangi bir çıkar çakışması olmadığını beyan etmiştir.

\section{Finansman}

Yazar bu yazının araştırma ve yazarlık sürecinde herhangi bir finansal destek almadığını beyan etmiştir. 